\title{
Functional status and severity of osteoarthritis in elderly is associated to the polymorphism of TNFA gene
}

\author{
Marcos Tadeu Parron Fernandes ${ }^{1,3}$, Karen Barros Parron Fernandes ${ }^{3,4}$, Fernanda Freitas Anibal ${ }^{5}$, \\ Walquíria Shimoya-Bittencourt ${ }^{6}$, Viviane Martins Santos ${ }^{6}$, Priscila Daniele de Oliveira Perrucini ${ }^{7}$ \\ and Regina Célia Poli-Frederico $2,4,8^{*}$
}

\begin{abstract}
Background: Osteoarthritis $(\mathrm{OA})$ is a major musculoskeletal disease with high prevalence in the elderly. The study of genetic polymorphisms of inflammatory mediators involved in OA may contribute to the elucidation of the complex pathophysiology of this disease and identification of susceptibility individuals.

Aim: This study aimed to evaluate the association between polymorphism at tumor necrosis factor alpha gene (SNP - 308 G/A TNFA) with presence, severity and functional status of osteoarthritis in elderly.

Methods: This study was characterized as case-control and encompassed 257 physically independent elderly (Mean Age: $68.55 \pm 5.2$; Minimum age: 60 and Maximum age: 82 ) were recruited. After this selection, the groups were divided in: 92 elderly individuals with osteoarthritis (case group) and 165 without the disease (control group).

Methods: The individuals were genotyped by the TaqMan real-time PCR system. The subjects were classified based on the degree of radiological impairment according to the criteria of Kellgren-Laurence and regarding functional impairment using the WOMAC and LEQUESNE questionnaires.

Results: TNFA gene polymorphic individuals (subjects harboring allele $A)$ are more affected by $O A\left(X^{2}=8.7, p=0.003\right)$, once they have major radiological lesion both in hip (Fisher-Freeman-Halton Test $=3.9, p=0.04$ ) and knee (FisherFreeman-Halton Test $=4.0, p=0.04$ ) as well as worse functional status assessed by the Lequesne questionnaire (MannWhitney, $p=0.04$ ). At the multivariate analysis, after adjustment for age, gender, body mass index, the presence of rare allele for TNFA (allele A) increases the susceptibility to OA development [OR: 1.87 (95\% Cl: 1.1-3.2)].
\end{abstract}

Conclusion: We conclude that the SNP - 308 G/A of TNFA gene may affect osteoarthritis susceptibility, severity and functional status of individuals with osteoarthritis.

Keywords: Osteoarthritis, Elderly, Genetic polymorphism, Tumor necrosis factor-alpha, Functional status

\section{Introduction}

Osteoarthritis (OA) is the most prevalent osteomuscular disease as well as the most common form of arthritis. It mainly affects elderly individuals, being a significant cause of limitations and incapacities at this population $[1,2]$. It is characterized by chronic and progressive loss

\footnotetext{
* Correspondence: reginafrederico@yahoo.com.br

${ }^{2}$ School of Medicine, Pontificia Universidade Católica Do Paraná, Londrina, PR, Brazil

${ }^{4}$ Doctoral Program in Rehabilitation Sciences, State University of Londrina and Pitágoras University UNOPAR, Londrina, PR, Brazil

Full list of author information is available at the end of the article
}

of articular cartilage components due to an imbalance between destruction and repair of the extracellular matrix, accompanied by changes in the synovium and subchondral bone [3, 4]. Although OA globally affects all joint tissues, cartilage destruction is the final pathway of the disease [1]. Clinically, it focuses mainly on the joints of the hips and knees, being followed with pain, sweling, loss of strength and atrophy of the periarticular muscles, inability to gait and reduced physical activity, representing major social burden and high costs to the health system [5-7].

(c) The Author(s). 2019 Open Access This article is distributed under the terms of the Creative Commons Attribution 4.0 International License (http://creativecommons.org/licenses/by/4.0/), which permits unrestricted use, distribution, and 
While inflammatory mechanisms are not fully understood, they play an important role in OA. The inflammation usually results from biomechanical stress, changes in chondrocyte function related to the aging process, and dysregulation of inflammatory cytokine activity [8, 9]. Chronic inflammation involves the production of mediators that are present in the synovial fluid, induce cartilage breakdown and hyperalgesia. Among the main mediators is tumor necrosis factor alpha (TNF-A), called proinflammatory cytokine, which play a central role in the pathophysiology of OA [10]. It is produced by chondrocytes, mononuclear cells, osteoblasts and synovial tissue, and act synergistically regulate the synthesis of components of the extracellular matrix by inhibiting the anabolic activity, and stimulation of production and release of catabolic inflammatory factors [11].

In OA, the chondrocyte is the cellular target of the action of this cytokine, whose receptors, TNFRI and TNFRII, are mainly in the cells of the joint surface [12]. TNF induce the synthesis of inflammatory factors, and enzymes such as nitric oxide, nitric oxide synthase, prostaglandin $E_{2}$, and cyclooxygenase-2, among others. Also increase the expression of metalloproteinases, which are proteolytic enzymes that destroy cartilage matrix as well as stimulate the production of other mediators such as interleukin-6 (IL-6) [12-16]. At the same time, suppress the anabolic activity of chondrocytes through the inhibition of proteoglycan and collagen type II [17].

Genetic factors are important in the etiology of OA. The single nucleotide polymorphisms (SNP) are an important object of study in understanding the complex mechanisms involved in the genesis and progression of OA. The TNF gene is located on $6 \mathrm{p} 21$, and a major polymorphisms involved in $\mathrm{OA}$ is the position - 308 of the promoter region, with exchange of guanine for adenine $(-308 \mathrm{G} / \mathrm{A}$; rs1800629). Several studies have shown that this polymorphism increase the genetic expression of this cytokine, related to higher prevalence of OA [18-26]. However, there is lack of information regarding a possible relationship between this genetic background and severity and functional status in elderly with OA.

The possibility of identifying individuals with increased susceptibility or lower predisposition to develop the disease has the potential to define preventive and therapeutic actions as early as possible with better clinical outcomes. Moreover, inflammatory mediators, such as TNF-alpha may represent future therapeutic targets in osteoarthritis. Thus, the aim was to study the polymorphism - $308 \mathrm{G} / \mathrm{A}$ of TNFA relating to the presence and severity of $\mathrm{OA}$ in the elderly.

\section{Materials and methods}

\section{Study design and population}

This case-control study comprised a sample from the project EELO (Study on Aging and Longevity), which was approved by the Ethics Committee of the UNOPAR (PP/0026/2013). All individuals have signed a written consent before any methodological procedure.

The inclusion criteria for the study were: being elderly (aged over 60 years), have OA of the hip and/or knee, confirmed by radiographic examination performed by medical specialist (case group) or being elderly with no clinical signs of osteoarthritis (control group). The control group was matched with case group considering gender and age.

The exclusion criteria for both groups were: having other rheumatic diseases, advanced osteoporosis, hip replacement or knee, corticosteroid use, sequelae of stroke or Parkinson's disease.

\section{Analysis of genetic polymorphism of TNFA Blood samples collect and DNA extraction}

From each patient, $5 \mathrm{ml}$ of peripheral blood were collected by venule puncture. Blood samples were stored at $-80^{\circ} \mathrm{C}$. DNA extraction was performed by using the kit PureLink - Invitrogen according to the manufacturer's instructions.

The evaluation of the purity and concentration of DNA was performed by analysis of absorbance in a spectrophotometer (NanoDrop ND-2000 - Thermo Scientific) at $260 \mathrm{~nm}$ and $280 \mathrm{~nm}$. Subsequently, the DNA dilution was made in ultrapure Milli- $Q^{\bullet}$ water to a final concentration of $30 \mathrm{ng} / \mu \mathrm{L}$.

\section{Analysis of the polymorphism in the TNFA gene by polymerase chain reaction in real time (RT-PCR)}

For the SNP analysis of the TNFA gene, the polymorphism at position - $308 \mathrm{G} / \mathrm{A}$ of TNF (rs1800629, assay ID: C_7514879_10) was chosen because it is a TAG SNP, with a perfect linkage disequilibrium with the other SNPs of the promoter region $(-238 \mathrm{G} / \mathrm{A}, \mathrm{rs} 361525$; $857 \mathrm{C} / \mathrm{T}, \mathrm{rs} 1799724 ;-863 \mathrm{C} / \mathrm{A}, \mathrm{rs} 1800630 ;-1031 \mathrm{~T} / \mathrm{C}$ rs1799964) [27], which means that these polymorphism are inherited simultaneously, which justifies to study only one of them.

The amplification technique of DNA fragments was performed by polymerase chain reaction (PCR) in real time by TaqMan system (Life technologies, Applied Biosystems, Foster City, USA).

The standard reaction contained $20 \mu \mathrm{L}$ final volume of $10 \mu \mathrm{L}$ with Genotyping TaqMan Master Mix (1x), 0,5 $\mu \mathrm{L}$ probe (1x) (Applied Biosystems, Foster City, USA) 7, $5 \mu \mathrm{L}$ ultrapure Milli- $\mathrm{Q}^{\circ}$ and $1 \mu \mathrm{L}$ of DNA $(30 \mathrm{ng} / \mu \mathrm{L})$. StepOne Plus thermocycler ${ }^{\mathrm{ma}}$ Real-Time PCR System (Applied Biosystems, Foster City, USA) with the following cycling used: 50 cycles of $60^{\circ} \mathrm{C}$ for $30 \mathrm{~s}, 95^{\circ} \mathrm{C}$ (pre denaturation), $95^{\circ} \mathrm{C}$ for $10 \mathrm{~min}$ for initial denaturation for $15 \mathrm{~s}$ (denaturation) and $60^{\circ} \mathrm{C}$ for $1 \mathrm{~min}$ and $30 \mathrm{~s}$ (primer annealing) and a final extension cycle of $30 \mathrm{~s}$ at 
$60{ }^{\circ} \mathrm{C}$. The evaluation of the results was performed by the StepOne Software v2.3.

\section{Assessment of the severity of osteoarthritis}

Individuals in the case group were asked to perform an $\mathrm{X}$-ray of the affected joint. All radiographs were analyzed by a radiologist, being useful not just to confirm the disease diagnosis but also to classify the disease severity using the criteria described by Kellgren and Lawrence [28] where the severity of osteoarthritis may be determined concerning radiographic findings as follows: Grade 0 - no radiographic changes; Grade I - doubtful space narrowing and possible marginal osteophytes; Grade II - possible joint space narrowing and defined osteophytes observed; Grade III - defined joint space narrowing, moderate multiple osteophytes, subchondral sclerosis and any possible deformity of bone contour and grade IV - remarkable joint space narrowing, severe subchondral sclerosis, definite deformity of bone contour and presence of large osteophytes [28].

Based on these criteria, the groups were re-categorized into two groups: with mild to moderate (grades I and II) radiographic changes and severe changes (grade III and IV).

\section{Evaluation of functionality related to osteoarthritis}

In order to assess the functional status of these patients, both Western Ontario and McMaster Universities Osteoarthritis Index (WOMAC) and LEQUESNE Index were used.

The WOMAC questionnaire was previously translated and validated to the Portuguese language and nowadays it is considered the gold standard for OA functional status evaluation according to the American College of Rheumatology. This questionnaire involves questions regarding pain, stiffness and function, where the highest score is the worst condition of the individual [29]. Additionally, the LEQUESNE Index was also used. This questionnaire was also translated to portuguese version and is recommended by the European League of Rheumatology (EULAR) to evaluate osteoarthritis functional status, comprising eleven questions involving pain, discomfort and functional limitation, specially related to functional status [30].

\section{Statistical analysis}

The Statistical Package for Social Sciences 20.0 (SPSS, UK) was used for statistical data analysis, with a confidence interval of $95 \%$ and a significance level of $5 \%(p<$ 0.05) established for all tests used.

For quantitative variables, the Shapiro-Wilk test was used and data with normal distribution were presented by mean and standard deviation as the data without normal distribution were presented as median and interquartile range.
The Chi Square was used as to verify that the genotype frequencies were in Hardy-Weinberg equilibrium as well as to assess possible associations between the presence of polymorphisms in the TNF gene with the occurrence and severity of osteoarthritis.

Moreover, the Mann-Whitney test was used to compare the functional status measured by WOMAC questionnaire and LEQUESNE index of individual with different genotypes.

In order to assess the influence of genetic polymorphisms on osteoarthritis etiology, a multivariate model (Logistic Regression) was used, considering the following variables: age, gender, body mass index and polymorphism of TNF gene. At this analysis, the dependent variable was the occurrence of osteoarthritis in elderly.

\section{Results}

\section{Sample characterization}

In this case-control study, 257 elderly individuals were recruited, being 162 women (63.0\%) and 95 men (37.0\%). Concerning this sample, 92 (35.8\%) individuals have osteoarthritis [21 men (22.8\%) and 71 women (77.2\%)], while 165 (64.2\%) didn't have this disease [74 men (44.8\%) and 91 women $(55.2 \%)]$.

The mean age of this sample was $68.55 \pm 5.2$ (Minimum age: 60 and Maximum age: 82 ). No difference was observed between the age of the case compared to the control group, according to Student $\mathrm{t}$ test $(p=0.26)$. Similarly, no difference was observed in body mass index when compared the case (median $=28.4$, interquartile range $=5.6$ ) and control group (median $=27.7$, interquartile range $=7$ ), according to the test Mann-Whitney test $(p=0.60)$.

Therefore, it may be assumed that the groups were similar considering age and body mass index.

\section{Gene polymorphism of TNF and susceptibility to osteoarthritis and related functional status}

The distribution of genotype frequencies are in accordance with Hardy-Weinberg equilibrium. Table 1 shows the distribution of genotypes and alleles for the polymorphism - $308 \mathrm{G} / \mathrm{A}$ of TNFA in patients with osteoarthritis and controls.

In healthy individuals, a greater proportion of GG genotype (67.9\%) was found and the percentage of $\mathrm{G}$ and $\mathrm{A}$ alleles were 78.2 and $21.8 \%$, respectively. For patients with osteoarthritis, the GG genotype was more frequent (53.3\%) and the percentages of $\mathrm{G}$ and $\mathrm{A}$ alleles were 67.9 and $32.1 \%$ respectively. It was observed that individuals carrying the A allele have increased susceptibility to osteoarthritis (Chi square $=8.7, p=0.003$, Table 1$)$. Thus, carriers of the $\mathrm{A}$ allele had twice the risk of developing osteoarthritis compared to individuals with the $\mathrm{G}$ allele $(\mathrm{OR}=1.7,95 \% \mathrm{CI}: 1.13-2.54, p=0.01)$. 
Table 1 Genotypics and Allelics frequencies of TNFA gene and the presence of osteoarthritis

\begin{tabular}{lll}
\hline & \multicolumn{2}{l}{ Presence of osteoarthritis } \\
\cline { 2 - 3 } & No & Yes \\
\hline Genotype Frequency & $112(67.9 \%)$ & $49(53.3 \%)$ \\
GG & $34(20.6 \%)$ & $27(29.3 \%)$ \\
GA & $19(11.5 \%)$ & $16(17.4 \%)$ \\
AA & $165(100.0 \%)$ & $92(100.0 \%)$ \\
Total & & \\
Allele Frequency* & $258(78.2 \%)$ & $125(67.9 \%)$ \\
G & $72(21.8 \%)$ & $59(32.1 \%)$ \\
A & $330(100.0 \%)$ & $184(100.0 \%)$ \\
Total & *Statistically significant, $\mathrm{x}^{2}$ test, $p<0.05$
\end{tabular}

An association between the presence of the polymorphism in the TNF gene and the severity of osteoarthritis assessed by radiographic lesions for both hip and knee osteoarthritis, according to Fisher-FreemanHalton Test ( $p=0.04$, Table 2).

Thus, we can estimate that individuals carrying the A allele have three times greater risk for serious radiological findings in cases of knee and hip osteoarthritis $(\mathrm{OR}=2.92$, 95\% CI: $1.16-7.34 ; p=0.03 ; \mathrm{OR}=3.2$. 95\% CI: $1.16-9.03 ; p=0.04$, respectively) when compared to individuals carrying the $\mathrm{G}$ allele.

Additionally, it was observed at the multivariate analysis that the gender and the polymorphism of TNFA gene were associated with osteoarthritis (Table 3).

Regarding the functional status of elderly patients with osteoarthritis, it was observed that individuals carrying the A allele have a poorer functionality according to the LEQUESNE questionnaire (Mann-Whitney, $p=0.04$ ), being this data shown in Fig. 1. However, no differences between groups concerning the WOMAC questionnaire were observed (Mann-Whitney test, $p>0.05$ ).

\section{Discussion}

OA is a progressive degenerative disease of the cartilage and articular structures, with important inflammatory component involved. Proinflammatory cytokines, such as TNF, are important mediators of this process by activating the production of metalloproteinases by chondrocytes, and stimulating the production of other proteins and cytokines, resulting in catabolic action and suppression of articular anabolism [16, 31]. The polymorphisms of these cytokine genes are studied in understanding the complex etiology and pathophysiology of OA, representing a potential tool for identifying risk for the disease, which can be useful in preventive and clinical management [21, 22, 24, 27-30, 32-34]. In this study we assessmnent the polymorphism - $308 \mathrm{G} / \mathrm{A}$ $T N F$ with the presence and severity of OA in the elderly.
Table 2 Relationship between the genotype and allele distributions of the TNF - G308A and the severity of knee and hip osteoarthritis according to the degree of radiological impairment

\begin{tabular}{lll}
\hline & \multicolumn{2}{l}{ Radiological Impairment } \\
\cline { 2 - 3 } & Mild & Moderate/Severe \\
\hline Hip & & \\
GG & & $05(41.7 \%)$ \\
GA & $19(65.5 \%)$ & $03(25.0 \%)$ \\
AA & $08(27.6 \%)$ & $04(33.3 \%)$ \\
Total & $02(6.9 \%)$ & $12(100.0 \%)$ \\
Allele Frequency* & $29(100.0 \%)$ & \\
G & & $13(54.2 \%)$ \\
A & $46(79.3 \%)$ & $11(45.8 \%)$ \\
Total & $12(21.7 \%)$ & $24(100.0 \%)$ \\
Knee & $58(100.0 \%)$ & $11(34.4 \%)$ \\
GG & & $14(43.7 \%)$ \\
GA & $14(73.7 \%)$ & $07(21.9 \%)$ \\
AA & $02(10.5 \%)$ & $32(100.0 \%)$ \\
Total & $03(15.8 \%)$ & \\
Allele Frequency* & $19(100.0 \%)$ & $36(56.2 \%)$ \\
G & $30(78.9 \%)$ & $28(43.8 \%)$ \\
A & $08(21.1 \%)$ & $64(100.0 \%)$ \\
Total & $38(100.0 \%)$ &
\end{tabular}

*Statistically significant, $\mathrm{x}^{2}$ test, $p<0.05$

The results showed significant correlation between the presence of the polymorphism and the presence of OA: individuals with polymorphic allele (GA and AA genotypes) have a higher incidence of the disease. Likewise, a significant association between the GA and AA genotypes and worse functional status (assessed by LEQUESNE questionnaire) when compared to homozygous (GG) individuals. However, similar results were not demonstrated through WOMAC questionnaire. One hypothesis that could explain this finding is that the LEQUESNE questionnaire has a higher profile assessment for the painful component when compared to the WOMAC questionnaire, which seems to have a closer relationship with the inflammatory component in question. Regarding the degree of radiological involvement, the SNP - 308 G/A has also meant a direct and significant association between the presence of the A allele and the severity of the lesions observed both hips and the knee radiographs. On the other hand, Sobhan et al. [35] in a case-control study followed by a meta-analysis, demonstrated that this polymorphism in question may not be associated with susceptibility of OA, as other authors complement, ratifying the lack of relationship between the - 308 SNP TNF and OA [32, 36]. 
Table 3 Multivariate analysis (Logistic Regression) considering the following variables: age, gender, body mass index and polymorphism of TNFA gene with the prevalence of osteoarthritis in elderly

\begin{tabular}{|c|c|c|c|c|c|c|}
\hline \multirow[t]{2}{*}{ Variables } & \multicolumn{3}{|l|}{ Univariate analysis } & \multicolumn{3}{|l|}{ Multivariate analysis } \\
\hline & Unadjusted Odds ratio & $\mathrm{Cl}(95 \%)$ & $p$ & Adjusted Odds ratio & $\mathrm{Cl}(95 \%)$ & $p$ \\
\hline \multicolumn{7}{|l|}{ Age Range } \\
\hline 60-70 years old & 1 & - & - & 1 & - & - \\
\hline$>70$ years old & 1.03 & - & 0.21 & - & - & - \\
\hline \multicolumn{7}{|l|}{ Gender } \\
\hline Male & 1 & - & - & 1 & & \\
\hline Female & 2.75 & $1.55-4.89$ & 0.001 & 2.67 & $1.48-4.8$ & $0.001^{*}$ \\
\hline \multicolumn{7}{|l|}{ Body Mass Index } \\
\hline Normal & 1 & - & - & 1 & - & - \\
\hline Overweight/Obesity & 1.28 & $0.77-2.20$ & 0.35 & - & - & - \\
\hline \multicolumn{7}{|l|}{ Polymorphism of TNFA } \\
\hline GG & 1 & - & & 1 & - & $0.02^{*}$ \\
\hline $\mathrm{AA}+\mathrm{GA}$ & 1.86 & $1.1-3.1$ & 0.02 & 1.87 & $1.1-3.2$ & \\
\hline
\end{tabular}

*Statistically significant at the final model

In contrast, there are several studies with results agreeing with our data, where the presence of the A allele at position - 308 has a direct relation to the prevalence and severity of knee and hip OA [21, 22, 24, 25, 33, 37], which is associated with a six-fold increase in transcriptional activity and higher levels of TNF- $\alpha$ protein $[38,39]$. In this same sense, Chen et al. 2018 and Kou et al. 2014 in metaanalyzes, with 983 and 257 cases of AO and 1355 and 305 controls, respectively, found an association between the $308 \mathrm{G} / \mathrm{A}$ polymorphism of TNF in relation to the higher risk of $\mathrm{OA}$.

However, it is important to state that these studies have usual specific findings and none of them had evaluated the genetic polymorphism with presence and severity of OA as well as the functional status of the same individuals. In a different way, we showed a correlation of genetic background not only with osteoarthritis, but also with clinical features.

Nevertheless, one limitation of this study is the inability to classify patients in d into ethnic subgroups, due to the wide variability in the population sample. Another limitation is the lack of serum as synovial levels of cytokines. On the other hand, the study groups showed no differences in body mass index, which excludes obesity bias, admittedly a predisposing factor for this disease $[40,41]$.

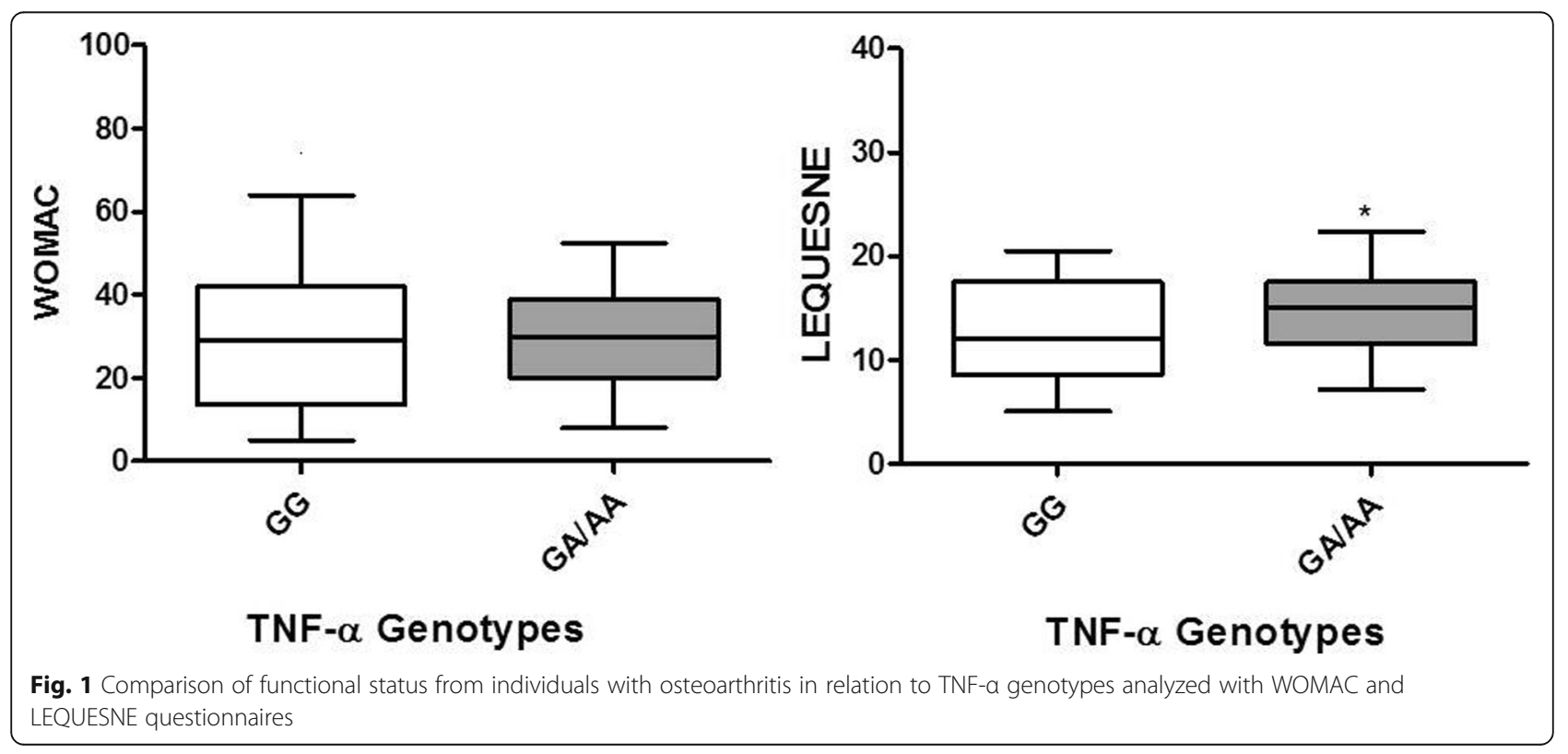


A possible explanation for all the results observed is that, in fact, polymorphism - $308 \mathrm{G} / \mathrm{A}$ of TNF may be related to a higher expression of TNFA. Due to the proinflammatory action of this cytokine, an increased secretion may lead to a shift of the metabolic balance in cartilage in favor of matrix loss, which may ultimately result in OA. In addition, TNFA appears to play a pivotal role in the imbalance between anabolic and catabolic process of OA patients. It can down-regulate the synthesis of major extracellular matrix components through the inhibition of the anabolic activity of chondrocytes [28], stimulate bone resorption by osteoclastic activity and even induce cellular apoptosis [38]. The TNF also stimulates chondrocytes to release matrix metalloproteinases (MMPs), which have the ability to degradate cartilage matrix proteins [31].

The SNP of TNF appears to have a causal relationship closer, but the lack of uniformity of the findings and conflicts observed in the literature may be due to factors related to ethnicity, gender or other yet unidentified. The multifactorial nature of OA makes it a condition of great complexity. Although this genetic predisposition has not yet been fully understood [42], polymorphisms are undoubtedly one of the factors involved in the genesis and progression of OA. Therefore, this study contributed to elucidate the complex mechanisms involved in genetic background of OA.

\section{Conclusion}

The results of this study demonstrate that the A allele of the TNF gene is associated with the predisposition of osteoarthritis and plays a role in the etiology, functionality and severity of hip and knee OA in the elderly.

\section{Authors' contributions}

Each author contributed individually and significantly to the development of the manuscript. MTPF began to approach the research problem and participated in all stages: project construction, bibliographic research, data collection, data analysis, discussion of results, conclusion and writing of the manuscript. KBPF and FFA participated in all stages, from project construction, data collection, data analysis, discussion of results, writing and critical review of the manuscript. VMS, PDOP and WS-B participated in data collection and analysis. RCPF participated in guiding all steps, from project construction, data collection, data analysis, discussion of results, manuscript writing and final review. All authors contributed strongly to the study. So al authors were responsible for all aspects of the work. All authors read and approved the final manuscript.

\section{Funding}

Nothing to declare.

\section{Availability of data and materials}

The supporting data should be made available to the editors and reviewers for manuscript evaluation purposes. The authors offer and agree on the availability of data and materials from this study, as well as transfer the publication and reproduction rights to this journal.

\section{Ethics approval and consent to participate}

This study was approved by the Ethics Committee of the UNOPAR. All individuals have signed a written consent before any methodological procedure.
Consent for publication

Not applicable.

\section{Competing interests}

The authors declare that they have no competing interests.

\section{Author details}

${ }^{1}$ Doctoral Program in Rehabilitation Sciences, State University of Londrina and University of Northern Parana (UEL/UNOPAR), Londrina, PR, Brazil. ${ }^{2}$ School of Medicine, Pontificia Universidade Católica Do Paraná, Londrina, PR, Brazil. ${ }^{3}$ Irmandade Santa Casa de Londrina Hospital (ISCAL), Londrina, PR, Brazil. ${ }^{4}$ Doctoral Program in Rehabilitation Sciences, State University of Londrina and Pitágoras University UNOPAR, Londrina, PR, Brazil. ${ }^{5}$ Morphology and Pathology Department, Federal University of São Carlos (UFSCar), São Carlos, SP, Brazil. ' University of Cuiabá (UNIC), Cuiabá, Mato Grosso, Brazil. ${ }^{7}$ University Anhanguera - UNIDERP (Universidade para o Desenvolvimento do Estado e da Região do Pantanal), Campo Grande, Mato Grosso do Sul Brazil. ${ }^{8}$ Laboratory of Molecular Biology, Biological and Health Sciences Center, Pitágoras University UNOPAR, Rua Marselha, 591 Jardim Piza. CEP, Londrina, PR 86041-140, Brazil.

Received: 26 March 2019 Accepted: 7 June 2019

Published online: 25 June 2019

\section{References}

1. Mathy-Hartert M, Hogge L, Sanchez C, Deby-Dupont G, Criellard JM, Henrotin Y. Interleukin-1 $\beta$ and Interleukin- 6 disturb the antioxidant enzyme system in bovine chondrocytes: a possible explanation for oxidative stress generation. Osteoarthr Cartil. 2007;16:756-63.

2. Sharma L, Kapoor D, Issa S. Epidemiology of osteoarthritis: an update. Curr Opin Reumatol. 2006;18:147-56.

3. Orita S, Koshi T, Mitsuka T, Miyagi M, Inoue G, Arai G, et al. Associations between proinflamatory cytokines in the synovial fluid and radiographic grading and pain-related scores in 47 consecutive patients with osteoarthritis of the knee. Musculoskelet Dis. 2011;12:1-8.

4. Goldring MB, Otero M, Tsuchimochi K, ljiri K, Li Y. Defining the roles of inflamatory and anabolic cytokines in cartilage metabolism. Ann Rheum Dis. 2008;67:75-82.

5. Pelletier JP, Martel-Pelletier J. DMOAD developments : present and future. Bulletin of the NYU Hospital for joint diseases. 2007;65:242-8.

6. Hunter DJ, McDougall JJ, Keefe FJ. The symptoms of OA and the genesis of pain. Rheum Dis Clin North Am. 2008;34(3):623-43.

7. Livshits G, Zhai G, Hart DJ, Kato BS, Wang H, Williams FMK, et al. Interleukin6 is a significant predictor of radiographic knee osteoarthrits. Arthrit Rheumatism. 2009;60:2037-45.

8. Goldring SR, Goldring MB. The role of cytokines in cartilage matrix degeneration in osteoarthritis. Clin Orthop. 2004:427:S27-36.

9. Goldring MB, Berenbaum F. The regulation of chondrocyte function by proinflamatory mediators : prostaglandins and nitric oxide. Clin Orthop. 2004:S37-46.

10. Bondeson J, Wainwright SD, Laudr S, Amos N, Hughes C. The role of sinovial macrophages and macrophage-producec cytokines in driving aggrecanases, matrix metalloproteinases and other destructive and inflammatory responses in osteoarthritis. Arthrit Res Ther. 2006;8:1-12.

11. Kapoor M, Martel-Pelletier J, Lajeunesse D, Pelletier JP, Fahmi H. Roles of proinflammatory citokines in the pathophysiology of ostheoartritis. Nature Rev Rheumatol. 2011;7:37-42.

12. Ohtori S, Takahashi K, Moriya H, Myers RR. TNF- $\alpha$ and TNF-a receptor type 1 upregulation in glia and neurons after peripheral nerve injury: studies in murine DRG and spinal cord. Spine. 2004;29:1082-8.

13. Poole AR, Alini M, Hollander AR. Cellular biology of cartilage degradation. In: Henderson B, Edwards JC, Pettipher ER, editors. Mechanisms and models in rheumatoid arthritis. London: Academic Press; 1997.

14. Border P, Solymar D, Sucharczuk A, Lindman B, Cannon P, Heller RA. Cytokine control of interstitial colagenase and collagenase-3 gene expression in human chondrocytes. J Biol Chem. 1996;271:23577-81.

15. lannone F, De Bari C, Dell'accio F, Covelli M, Patella V, Lo Bianco G, Lapadula G. Increased expression of nerve growth factor (NGF) and high affinity NGF receptor (p140 TrkA) in human osteoarthritic chondrocytes. Rheum. 2002;41: $1413-8$. 
16. Kobayashi M, Squires GR, Mousa A, Tanzer M, Zukor DJ, Antoniou J, et al. Role of interleukin-1 and tumor necrosis factor a in matrix degradation of human osteoarthritic cartilage. Arthrits Rheum. 2005;52:128-35.

17. Goldring MB, Otero M. Inflammation in osteoarthritis. Cur Opin Rheumatol. 2011;23(5):471-8

18. Sezgin M, Erdal ME, Altintas ZM, Ankarali HC, Barlas LO, Turkmen E, et al. Lack of association polymorphisms of the IL1RN, IL1A, and IL1B genes with knee osteoarthritis in Turkish patients. Clin Invest Med. 2007;30:E86-92.

19. Kanoh T, Hasegawa Y, Masui T, Yamaguchi J, Ishiguro N, Hamajima N. Interleukin-1 beta gene polymorphism associated with radiographic signs of osteoarthritis of the knee. J Orthop Sci. 2008;13:97-100.

20. Ni H, Shi D, Dai J, Qin J, Xu Y, Zhu L, et al. Genetics polymorphisms of interleukin-1 beta $(-511 \mathrm{C} / \mathrm{T})$ and interleukin-1 receptor antagonist (86bpVNTR) in susceptibility to knee osteoarthritis in a Chinese Han population. Rheumatol Int. 2009:29(11):1301-5.

21. Han L, Song JH, Yoon JH, Park YG, Lee SW, Choi YJ, et al. TNF- $a$ and TNF- $\beta$ polymorphisms are associated with susceptibility to osteoarthritis in a korean population. Korean J Pathol. 2012;46:30-7.

22. Ji B, Shi J, Cheng X, Zhou J, Zhou Q, Cao C, et al. Association analysis of two candidate polymorphisms in the tumor necrosis factor-a gene with osteoarthritis in a Chinese population. Int Orthop. 2013:37:2061-3.

23. Kaarvatn MH, Jotanovic Z, Mihelic R, Etokebe GE, Mulac-Jericevic B, Tijanic T, et al. Associations of the interleukin-1 gene locus polymorphisms with risk to hip and knee osteoarthritis : gender and subpopulation differences. Scand J Immunol. 2013;77:151-61.

24. Cheng XY, Cao CF, Ji B. Association of tumor necrosis factor-alpha -308 polymorphism with osteoarthritis in a Chinese population. Chin J Orthop Trauma. 2013:15(7):607-9.

25. Galil SMA, Ezzeldin N, Fawzy F, El-Boshy M. The single-nucleotide polymorphism (SNP) of tumor necrosis factor a $-308 \mathrm{G} / \mathrm{a}$ gene is associated with early-onset primary knee osteoarthritis in an Egyptian female population. Clin Rheumatol. 2017:36:2525-30.

26. Chen J, Wu Y, Yu J, Shen J. Association between tumor necrosis factor alpha rs1800629 polymorphism and risk of osteoarthritis in a Chinese population. Braz J Med Biol Res. 2018;51(8):e7311.

27. Boraska V, Rayner NW, Groves CJ, Frayling TM, Diakite M, Rockett KA, Kwiatkowski DP, Day-Williams AG, McCarthy MI, Zeggini E. Large-scale association analysis of TNF/LTA gene region polymorphisms in type 2 diabetes. BMC Med Genet. 2010;11:69-76.

28. Kellgren JH, Lawrence JS. Radiological assessment of osteoarthrosis. Ann Rheum Dis. 1957;16:494-502.

29. Ivanovitch MF. Translation and validation of the quality of life questionnaire specific WOMAC osteoarthritis (Western Ontario and McMaster osteoarthritis universities index) to portuguese language. São Paulo: Federal University of São Paulo; 2002. p. $87 f$.

30. Lequesne MG. The algofunctional indices for hip and knee osteoarthritis. J Rheumatol. 1997:24:779-81.

31. Lefebvre V, Peeters-Joris C, Vaes G. Modulation by interleukin 1 and tumor necrosis factor alpha of production of collagenase, tissue inhibitor of metalloproteinases and collagen types in differentiated and dedifferentiated articular chondrocytes. Biochim Biophys Acta. 1990;1052:366-78.

32. Sezgin MM, Barlas LO, Ankarali HC, Altintas ZM, Türkmen E, Gökdogan T, et al. Tumor necrosis factor alpha -308G/a gene polymorphism: lack of association with knee osteoarthritis in a turkish population. Clin Exp Rheumatol. 2008:26:763-8.

33. Muñoz-Valle JF, Martin-Márquez BT. 308 tumor necrosis factor-alpha promoter pollymorfism in patients with rheumatoid arthritis and osteoarthritis in the west of Mexico: preliminary results. Rev Vaccimonitor. 2002:11(4):4-12

34. Jotanovic Z, Etokebe GE, Mihelic R, Kaarvatn MH, Mulac-Jericevic B, Tijanic T, et al. IL-1B -511 (G/a) and IL1RN (VNTR) allelic polymorphisms and susceptibility to knee osteoarthritis in Croatian population. Rheumatol Int. 2012;32:2135-41.

35. Sobhan MR, Mahdinezhad-Yazdi M, Aghilik Z-SM, Rastegar S, SadeghizadehYazdi J, Neamatzadeh H. Association of TNF-a-308 G > a and -238G > a polymorphisms with knee osteoarthritis risk: a case-control study and metaanalysis. J Orthop. 2018;15:747-53.

36. Muñoz-Valle JF, Oregón-Romero E, Rangel-Villalobos H, Martínez-Bonilla GE, Castañeda-Saucedo E, Salgado-Goytia L, et al. High expression TNF alpha is associated with -308 and -238 TNF alpha polymorphisms in knee osteoarthritis. Clin Exp Med. 2014;14:61-7.
37. Nicklas BJ, Mychalecky J, Kritchevsky S, Palla S, Lange LA, Lange EM, et al. Physical function and its response to exercise: associations with cytokine gene variation in older adults with knee osteoarthritis. J Gerontol. 2005;60: 1292-8.

38. Kou S, Wu Y. Meta-analysis of tumor necrosis factor alpha -308 polymorphism and knee osteoarthritis risk. Musculoskelet Disord. 2014;15:373.

39. Zhang TC, Zhao YQ, Hu GL, Liu XQ, Huang XK. The relationship between tumour necrosis factor-a gene polymorphism and susceptibility and clearance of the persistent hepatitis B virus infection in a Chinese population: a meta-analysis. Clin Microbiol Infect. 2014;20(3):227-34.

40. Felson DT, Zhang Y. An update on the epidemiology of knee and hip osteoarthritis with a view to prevention. Arthrit Rheumatism. 1998;41:1343-55.

41. Kamarainem OP, Solovieva S, Vehmas T, Luoma K, Riihimaki H, Ala-Kokko L, et al. Common interleukin-6 promoter variants associate with the more severe forms of distal interphalangeal osteoarthritis. Arthritis Res Ther. 2008; 10(1):1-9.

42. Gari MA, AlKaff M, Alsehli HS, Dallol A, Gari A, Abu-Elmagd M, Kadam R, et al. Identification of novel genetic variations affecting osteoarthritis patients. Med Genet. 2016;17(Suppl1)68):9-13.
Ready to submit your research? Choose BMC and benefit from:

- fast, convenient online submission

- thorough peer review by experienced researchers in your field

- rapid publication on acceptance

- support for research data, including large and complex data types

- gold Open Access which fosters wider collaboration and increased citations

- maximum visibility for your research: over $100 \mathrm{M}$ website views per year

At $\mathrm{BMC}$, research is always in progress.

Learn more biomedcentral.com/submissions 